\title{
How We Heal: Genealogical Narratives of Healing among San Lázaro Devotees
}

\author{
Elaine Penagos
}

check for

updates

Citation: Penagos, Elaine. 2021.

How We Heal: Genealogical

Narratives of Healing among San

Lázaro Devotees. Genealogy 5: 18.

https://doi.org/10.3390/

genealogy5010018

Received: 28 September 2020

Accepted: 25 February 2021

Published: 28 February 2021

Publisher's Note: MDPI stays neutral with regard to jurisdictional claims in published maps and institutional affiliations.

Copyright: (C) 2021 by the author. Licensee MDPI, Basel, Switzerland. This article is an open access article distributed under the terms and conditions of the Creative Commons Attribution (CC BY) license (https:// creativecommons.org/licenses/by/ $4.0 /)$.
Graduate Division of Religion, Emory University, Atlanta, GA 30322, USA; elaine.penagos@emory.edu

\begin{abstract}
Healing is the basis of belief in San Lázaro, a popular saint among Cubans, CubanAmericans, and other Latinx peoples. Stories about healing, received through faith in San Lázaro, are typically passed on through family members, rendering them genealogical narratives of healing. In this photo essay, the author draws on her maternal grandmother's devotion to San Lázaro and explores how other devotees of this saint create genealogical narratives of healing that are passed down from generation to generation. These genealogical narratives of healing function as testaments to the efficaciousness of San Lázaro's healing abilities and act as familial avenues through which younger generations inherit belief in the saint. Using interview excerpts and ethnographic observations conducted at Rincón de San Lázaro church in Hialeah, Florida, the author locates registers of lo cotidiano, the everyday practices of the mundane required for daily functions and survival, and employs arts-based methods such as photography, narrative inquiry, and thematic poetic coding to show how the stories that believers tell about San Lázaro, and their experiences of healing through faith in the saint, constitute both genealogical narratives of healing and genealogical healing narratives where testimonies become a type of narrative medicine.
\end{abstract}

Keywords: San Lázaro; healing; Cuban; narratives; faith; lo cotidiano; arts-based methods

\section{Introduction}

Living through a global pandemic gave me pause and cause to reflect on the importance of faith, family, and community in my life. The first few months of stay-at-home orders were a strange mix of frustration, sadness, worry, and a slew of other emotions that I still cannot articulate. Physically isolating from most of the world also forced introspection regarding many of the quotidian aspects of my day-to-day life. Thinking about lo cotidiano (the quotidian), in terms of the everyday practices of the mundane required for daily functions and survival-most famously written about by mujerista theologian Ada Maria Isasi-Díaz-I reflected on the question of what it means to heal. Contemporarily, the need for healing is often thought of as an individual necessity, one that has been increasingly perceived as only being met through the marvels of science and biomedicine. However, my life experiences as a gay Latina have taught me that healing goes beyond therapies administered in a clinical setting or the contents of a prescription bottle. For me, the word "heal" is a holistic verb that encompasses more than just the capabilities of biomedicine; healing requires a unification of science and culture, of faith and reason-an alchemy of all the things, ordinary and extraordinary, that comprise being in and of this world.

As a Latina with Cuban and Colombian roots, my beliefs have always teetered on the line between popular Catholicism and Afro-Cuban religious traditions. My faith practices are a product of familial traditions, beginning with those I learned from my abuela, my maternal grandmother. As a child, stories contributed significantly to my religious formation (I never received formal religious instruction beyond infant baptism in the Roman Catholic tradition). Stories and testimonies from family and friends helped me delineate what, as a child, I perceived as real, possible, magical, miraculous, or untrue. I understand the seemingly ordinary act of storytelling as an integral part of lo cotidiano-a concept born 
from and for Latinx people specifically, but I suggest applicable to all marginalized and oppressed communities generally. Isasi-Díaz maintains that understanding lo cotidiano is integral to understanding the lived-experiences of Latinas specifically and all Latinx peoples generally (Isasi-Díaz 2002, p. 8). As an adult, childhood memories of my abuela praying to San Lázaro and healing my recurrent ear infections with Catholic prayers and plastic bottles of holy water were formative in my academic study of religion. Moreover, the interrogation of stories as part of lo cotidiano and the generative and healing roles stories play in helping Black, Indigenous, and people of color reimagine and remake the world is at the heart of my vocation as a scholar of religion.

Within the broad array of Latinx religious practices, faith, belief, and spirituality are very often genealogical in nature, meaning that we become religious subjects not through authoritative religious instruction but through the teachings of our families. Whether we practice Catholicism, Santería/Lucumí, Espiritismo, Curanderismo, or other religious traditions, we often arrive at religion through familial ties and ancestors. While this is arguably not exclusive to Latinx communities, the stories that make up our personal canons of religious narratives are by and large rooted in our genealogies. For example, devotion to saints, both popular and canonized, demonstrates how genealogical narrativesparticularly about healing in the broadest conception of the term-are passed down from generation to generation. These genealogical narratives of healing provide individuals with familial evidence of the efficacy of faith. They are also instructive since their telling often includes a recounting of ritual practices and effective divine reception as confirmed by the experience of healing received by the story's protagonist. Thus, these genealogical narratives of healing also become genealogical healing narratives since the passing down of stories contain a certain power to heal in and of themselves.

Rita Charon's conception of narrative medicine, "medicine practiced with the narrative competence to recognize, absorb, interpret, and be moved by the stories of illness," is useful for understanding how the stories about San Lázaro and the stories of his devotees contribute to a genealogy of healing among the saint's devout (Charon 2006, p. vii). Narratives and storytelling are central to our ability to understand each other. They are often the primary tools we reach for to transmit histories and important lessons (Charon 2006, p. vii). Building on Charon's work, I suggest that stories also have healing abilities, making them a type of narrative medicine. Through stories about San Lázaro and those healed by him, the healing potential of narratives transforms into a corpus of narrative medicine, which becomes genealogical healing narratives when passed on through family. In turn, these stories can ease suffering caused by physical, emotional, or psychological illness, and through their optimistic outcomes, can provide hope for the afflicted.

\section{Methodology for Lo Cotidiano}

Arts-based methods exemplify an interdisciplinary approach to religious studies from the perspective of la vida cotidiana (the quotidian life), another way in which Latinx scholars qualify lo cotidiano. Working from lo cotidiano creates aesthetic productions that draw on ontologies and epistemologies that have historically not been privileged as founts for academic knowledge. Arts-based methods drawing from lo cotidiano demonstrate rich, nuanced, and complex knowledges and ways of knowing. Carmen Nanko-Fernández maintains that using lo cotidiano as a departure point "draws on the wisdom, observations, and methods of other disciplines, fields of study, and interpretive perspectives. These include, but are not limited to, the natural sciences and social sciences; liberationist, postcolonial, diasporic, migration, linguistic, and culture studies; gender studies, and feminist and queer theories; critical race theory, literary theory, and philosophy; grassroots activism, street art, and even the culinary arts" (Nanko-Fernández 2015, p. 17).

To get to the heart of the many stories I heard about San Lázaro from his devout, I use a composite methodology that privileges arts-based methods and merges photography, narrative inquiry, and thematic poetic coding with ethnography and autoethnography. Narrative inquiry is used based on Patricia Leavy's description of the method as a way to 
“collaboratively access participants' life experiences and engage in a process of storying and re-storying in order to reveal multidimensional meanings and present an authentic and compelling rendering of the data" (Leavy 2015, p.46). Using ethnographic and interview information gathered during fieldwork I conducted at Rincón de San Lázaro church in Hialeah, Florida, during the summer of 2016, I apply narrative inquiry and thematic poetic coding to my interview and observation notes in order to draw out how the stories told about San Lázaro constitute genealogical narratives of healing. My turn to poetic coding aims to use the words of my interlocutors as well as my own to construct a "feeling picture" that "create(s) sensory scenes where meaning emerges from the careful construction of both language and silences. In this way, a poem can be understood as evoking a snippet of human experience that is artistically expressed as in a heightened state" (Leavy 2015, p. 66). The participant-voiced and researcher-voiced poems and photographs presented here provide insight into the everyday expressions of faith of devout believers in San Lázaro-Cubans and other Latinx peoples-who live in South Florida and worship at Rincón de San Lázaro church. Included are pictures and stories of my abuela, who, like other devotees to whom I spoke, passed on her faith in San Lázaro by sharing her lived experiences and dreams in which the saint revealed himself to her. Genealogically, my abuela is the progenitor for many of my faith and healing practices. My uncle, her son, also inherited his faith in San Lázaro from my abuela. Collectively, the images and poems in this photo essay represent part of the spectrum of religious and cultural practices and $l a$ vida cotidiana of multiple generations of San Lázaro devotees.

Including autoethnography in my methodology allows me to utilize and reflect on personal and familial experiences with San Lázaro that enrich this project (Ellis et al. 2011, p. 3). I use autoethnography following its definition by Carolyn Ellis, Tony E. Adams, and Arthur P. Bochner, who describe the method as, "An approach to research and writing that seeks to describe and systematically analyze (graphy) personal experience (auto) in order to understand cultural experience (ethno)" (Ellis 2004; Holman Jones 2005). According to Ellis, Adams, and Bochner, "When researchers write autoethnographies, they seek to produce aesthetic and evocative thick descriptions of personal and interpersonal experience ... Thus, the autoethnographer not only tries to make personal experience meaningful and cultural experience engaging but also, by producing accessible texts, she or he may be able to reach wider and more diverse mass audiences that traditional research usually disregards ..." (Ellis et al. 2011, p. 3). As an integral part of utilizing an autoethnographic method, I acknowledged and discussed my cultural heritage and positionality as a scholar/believer with my interlocutors and with the broader religious community attending Rincón de San Lázaro church. I accomplished this disclosure in two ways; first, I visited the church a few times as a co-performative witness. This step is central to my methodological approach described by Elaine Peña as an approach to fieldwork in which the body is placed "in the immediate context of devotional practice" (Peña 2011, p. 152). Co-performative witnessing included going to the church on weekdays and attending formal services on weekends. Second, on the day where I conducted the bulk of my interviews, I arranged with the bishop to introduce myself to the congregation and say a few words about the work I was doing there. Standing in front of a full church on a Sunday morning gave me the opportunity to tell my own San Lázaro stories to a room of his devotees and allowed the congregation members to view me as part of the community. Like many of them, I am interested in San Lázaro because of a beloved family member, and the divulging of this fact seemed to resonate with many of the enthusiastic parishioners who approached me after the service. Through the stories of my abuela, a Cuban Catholic devotee of San Lázaro, I can relate to my interlocutors' stories at Rincón de San Lázaro church.

\section{Historical Context}

A precise history of San Lázaro veneration in Cuba is difficult to trace. The San Lázaro popularly worshipped among Cubans, Cuban-Americans, and other Latinx peoples is an amalgam of the resuscitated Lazarus of Bethany from the Gospel of John, the poor man 
Lazarus from the parable in the Gospel of Luke, and the Yoruba orisha of disease known as Babalú Ayé in Santería/Lucumí. The orisha are deities in the Santería/Lucumí pantheon associated with specific energies, concepts, or elements of nature. Due to his multifaceted identity, devotion to San Lázaro serves as a place of intersectionality where African heritage religions and Catholic religious beliefs converge to form a powerful system of healing available to his devotees regardless of religious or cultural background.

According to Michelle A. Gonzalez, "There is no historical documentation of how devotion to the Lucan Lazarus began in Cuba. The origins of Lazarus and his iconography are unknown" (Gonzalez 2006, p. 114). The Lucan Lazarus that Gonzalez refers to is represented by the figure of the poor man from Jesus's parable in the Gospel of Luke and is the one at the heart of Cuban San Lázaro devotional traditions. Mercedes Cros Sandoval's research on Afro-Cuban religions offers some additional insight into the possible origins of devotion to San Lázaro in Cuba. Cros Sandoval suggests that veneration of the popular saint began with a leprosy sanitarium constructed in the town of El Rincón in 1681. Administration of this sanitarium passed to an order of nuns in 1854, and a chapel dedicated to Saint Lazarus was consequently built next to the hospital. However, the image of the saint used in the chapel depicted "a leper, walking painfully with the aid of crutches, assisted by two dogs" (Cros Sandoval 2006, p. 264). According to Cros Sandoval, "the saint worshipped at this shrine gained a large following. He was perceived as a saint of great compassion for people who were suffering as he himself had suffered. He also had the reputation for having great healing powers" (Cros Sandoval 2006, p. 264). By naming the chapel after Saint Lazarus but using an image akin to the poor man Lazarus, the nuns unofficially canonized the Lucan Lazarus and merged his identity with that of the resuscitated Lazarus of Bethany in the Cuban imagination.

Early in the twentieth century, a new chapel was constructed on the sanitarium grounds, which eventually became the Santuario Nacional de San Lázaro (National Sanctuary of San Lázaro). Since its construction, the Santuario Nacional de San Lázaro became a place of prominence for devotees of the saint, who consequently popularized the chapel as a major site of pilgrimage. In Cuba, the Santuario Nacional de San Lázaro is the second most visited site of pilgrimage after the Basílica Santuario Nacional de Nuestra Señora de la Caridad del Cobre (National Shrine Basilica of Our Lady of Charity) (Colaboradores de EcuRed n.d.). It should be noted that Our Lady of Charity is the official patron saint of Cuba, recognized and canonized by the Roman Catholic church. However, while Santuario Nacional de San Lázaro is also Roman Catholic, the saint that receives thousands of visitors at the church is not the canonized Saint Lazarus-Bishop of Marseilles, the resuscitated Lazarus of Bethany-although an effigy to him is also present at the church. The saint that brings the innumerable masses to the church is instead the popular, unofficial, uncanonized San Lázaro. His effigy is that of an older man wearing ragged clothing, holding himself up on crutches, and covered in leprous sores. At his sides are dogs that both accompany him and lick his wounds to relieve his pain. As Gonzalez notes, "This is the Lazarus of Cuban and Cuban-American devotions. While they consider him a saint, he is not the official saint of the Catholic Church ... This is a different Lazarus ... he is the object of one of the most significant devotions in Cuban/Cuban American religiosity" (Gonzalez 2006, p. 112). See Figures 1 and 2. 


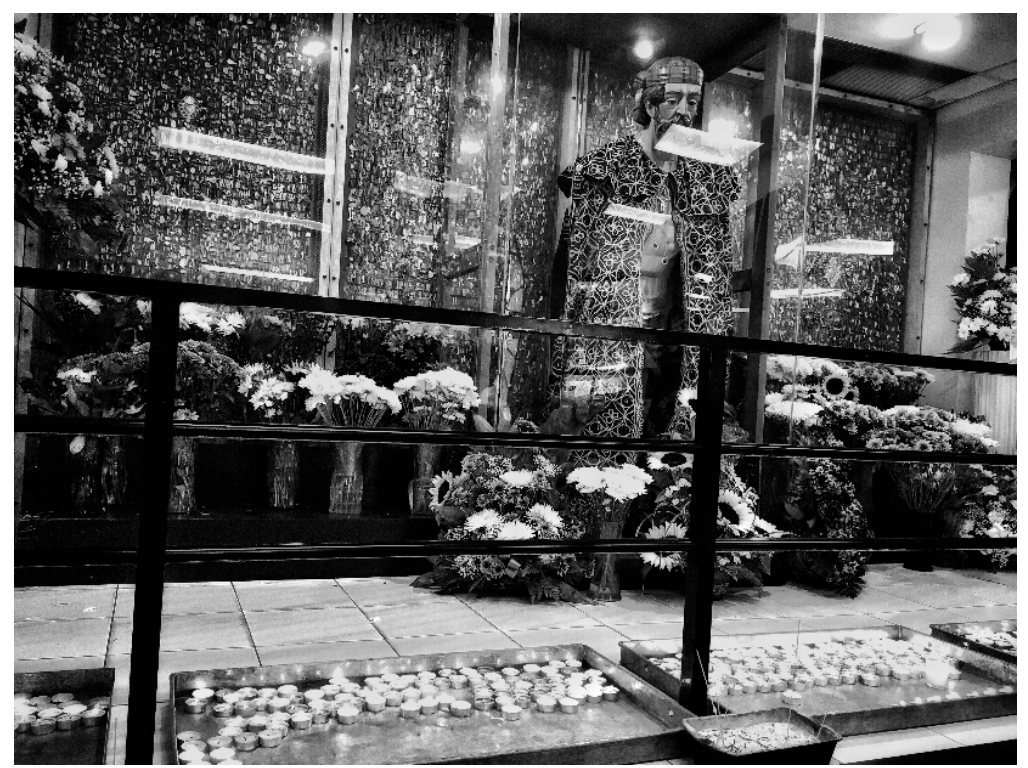

Figure 1. The statue of San Lázaro at Rincón de San Lázaro church stands on an elevated altar, behind metal barriers, and encased in protective plexiglass. Behind the statue are innumerable milagritos, gold, and silver charms shaped as different body parts, that the devout bring to the saint as offerings and thanks for the healing of their various ailments. Photograph by author 2016.

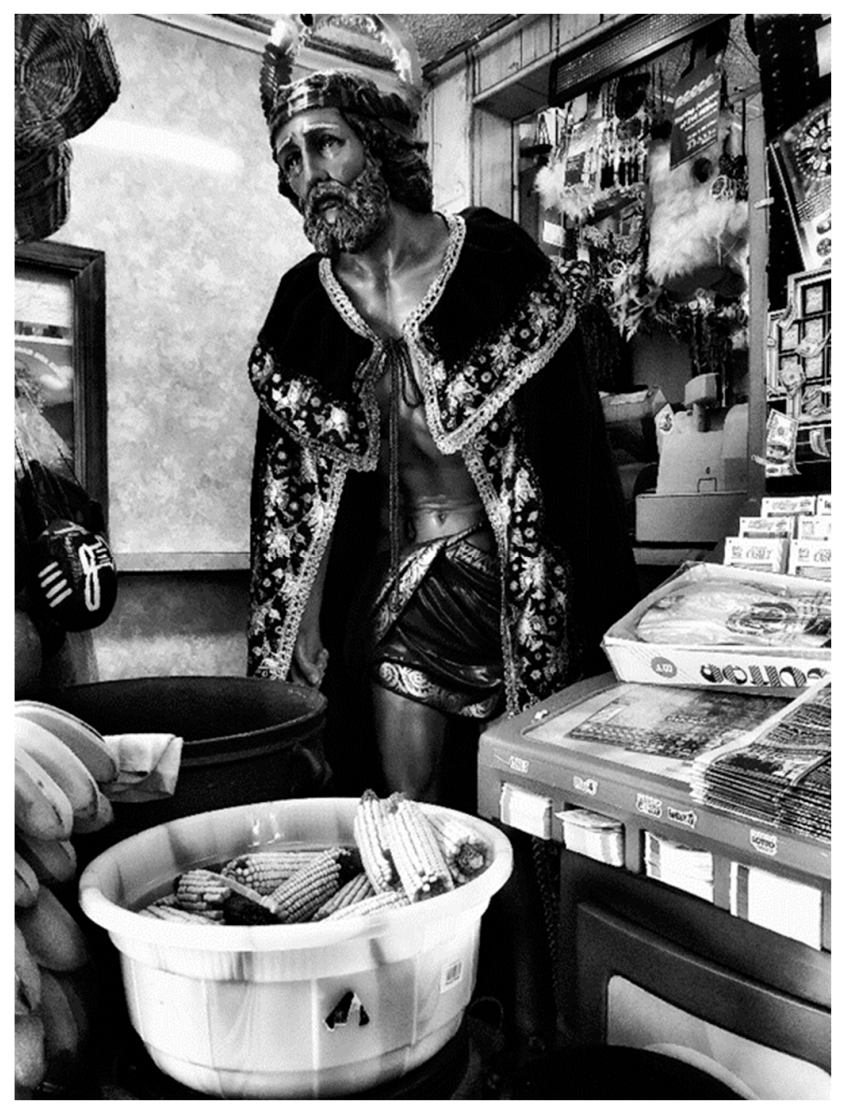

Figure 2. Located across the street from Rincón is a botanica, named Botanica San Lázaro, that caters to the religious supply needs of practitioners of Santería/Lucumí who also frequent the church. Patrons are greeted by a somber towering statue of San Lázaro, who stands in front of the register, next to a stand of empty lottery tickets which visitors to the store can purchase along with candles, amulets, and a plethora of other religious goods. Photograph by author 2016. 
In the United States, devotion to San Lázaro can be traced back to the mid-twentieth century when Cubans began to leave the island en masse after Fidel Castro's 1959 revolution. However, relocation to the U.S. does not appear to have negatively impacted devotion to San Lázaro among the arriving Cuban faithful. The implications of Cuban migration to the United States on San Lázaro veneration occurred primarily at the level of institutionalized religion. Due to the Vatican's limited presence in Cuba during the first three decades of Fidel Castro's regime (1959-1992), San Lázaro's status as an unofficial saint was often unknown amongst the laity that encountered the Catholic Church upon arrival in the U.S. The Catholic Church in Miami faced the arduous task of redirecting Cuban devotion from the popular San Lázaro to the canonized Saint Lazarus, Bishop of Marseilles. Gonzalez notes that this effort from the Catholic Church was part of a campaign that sought to "evangelize the Cuban-American population and strip this Afro-Cuban devotion from the Cuban-American ethos" (Gonzalez 2006, p. 113). Removing images of the popular San Lázaro was at the center of the Catholic Church's clerical efforts. Consequently, the Catholic Church constructed San Lázaro Church in 1986, just over four miles away from where a group of Cuban San Lázaro devotees would construct a surrogate home for their beloved saint.

Named after the Santuario Nacional de San Lázaro in the town of Rincón, Cuba, Rincón de San Lázaro is a proxy for the church on the island for Cubans, Cuban-Americans, and other devotees living in South Florida. According to its website, the church was founded by a group of Cubans who emigrated to the United States in the early 1970s. Compelled by a "need to continue professing their devotion to San Lázaro," they rented a small office space in the city of Hialeah, where they could venerate the popular saint they left behind in Cuba. Over the years, this group of San Lázaro devotees worked to raise funds, which eventually allowed the construction of a stand-alone church (Rincón de San Lázaro, About Us). The church constructed in Hialeah by devotees of San Lázaro attempts to recreate the sacred corporealness of the Santuario Nacional de San Lázaro. It is a space where the identity of San Lázaro is not a contested issue and a place where the clergy and practitioners of multiple faiths peacefully coexist. Although all are welcome at Rincón de San Lazaro, the church's identification as an Apostolic Catholic church is reminiscent of Cuba's Christian colonial history. The construction of identities stemming from the African Diaspora, first in Cuba then in the United States, is important for understanding belief in San Lázaro and the various ways in which the devout understand his identity and powers to heal. As Gonzalez notes, "The Afro-Cuban roots of this figure have grounded him in the broader Cuban ethos" (Gonzalez 2006, p. 114). Indeed, whether the devout openly acknowledge it or not, it is the inclusion of the orisha Babalú Ayé's capabilities that transform the beggar Lazarus figure presented in the effigy of San Lázaro, into a powerful healer in Cuban culture. Perhaps the most remarkable feat accomplished by the construction of Rincón de San Lázaro in Hialeah was creating a point for the intersection of African heritage religions and Catholicism, where all devotees can come and petition the saint to heal them.

\author{
Bent and solemn \\ Crutches hold your \\ Tired, broken body \\ Your back heavy with our pleas \\ Upon your altar \\ Encased in plexiglass \\ On your feast day or \\ Across the street \\ Next to charms of gold \\ Cobs of toasted corn \\ And lottery tickets \\ Filled with hopeful promises \\ You stand
}


With the weight of our ailments

Of our illnesses

The heavy burden of our prayers

\section{Abuela}

I first learned about San Lázaro from my abuela. The saint has been a constant presence in her house and thus in my life since I can remember-una presencia cotidiana (a quotidian presence). My abuela has always had an altar for the saint. When she lived in an apartment, she placed her altar in a prominent spot where San Lázaro and a small collection of other saints and archangels would stand together. During the years that my abuela was fortunate enough to live in a house, San Lazaro's altar grew in prominence and moved into a whitetiled concrete and glass enclosure that sat just outside the front door. For devotees like my abuela, celebrating San Lázaro's feast day in December necessitates that she buys a new purple dress and adorn the saint's altar with purple flowers (purple is the color associated with both San Lázaro and Babalú Ayé). See Figure 3. To the unfamiliar, San Lázaro's image is strikingly somber. He is most often depicted as an older man on crutches, covered in sores from either leprosy, smallpox, or syphilis (depending on the origin story), and accompanied by dogs that lick his wounds. San Lázaro is usually portrayed wearing a purple loincloth or tattered clothes that remind those who view him that he was a poor man. However, in contrast to his bent body, sores, and meager clothing, his statues are usually draped with elaborate purple capes embellished with gold attributes as a symbol of his divine kingly status. Prayer cards featuring the saint typically omit the cape in favor of a more modest depiction, but his sores, dogs, and crutches are always present.

My abuela has always been crafty. When I was a little girl, her artistic activities included making my sister and I dresses out of oversized t-shirts, adorning ceramic cherub figurines, and making elaborate dried flower arrangements with flowers she carefully dried herself, to name just a few. She also used her talents to show her profound adoration for San Lázaro. As a devotional act, my abuela would buy pieces of purple velvet or satin and burlap cloth and would hand sow gold embellishments like rhinestones and gold lace trimming on the capes she made for the saint. For as long as I can remember, the San Lázaro statue in my abuela's home has always been draped in one of her stunning handmade capes. As an integral part of the materiality of sacredness, the color purple serves as a reference to the rich man's clothing in the Gospel of Luke and is the primary color representing Babalú Ayé in Santería. San Lázaro's purple cape symbolizes the Catholic belief of God's preferential option for the poor and Babalú Ayé's eventual kingship, as mentioned in his patakis, origin stories (Canizares and Lerner 2000, pp. 7-8, 12,14). For his followers, the purple cape also symbolizes the possibility of liberation from their pain and struggles and the rewards that the poor, sick, and oppressed are promised in the afterlife. My abuela's interweaving of fine purple fabrics and burlap cloth is indicative of her understanding of this aspect of San Lázaro's meaning. San Lázaro's cape, merging a range of disparate elements, evokes Isasi-Diaz's description of lo cotidiano as "where we first meet and relate to the material world that is made up not only of physical realities but also is made up of how we relate to that reality (culture), and how we, understand and evaluate that reality and our relationship with it (history). Lo cotidiano is necessarily entangled in material life and is a key element of the structuring of social relations and its limits. Lo cotidiano situates us in our experiences. It has to do with the practices and beliefs that we have inherited, with our habitual judgments, including the tactics we use to deal with the everyday" (Isasi-Díaz 2002, p. 8). 


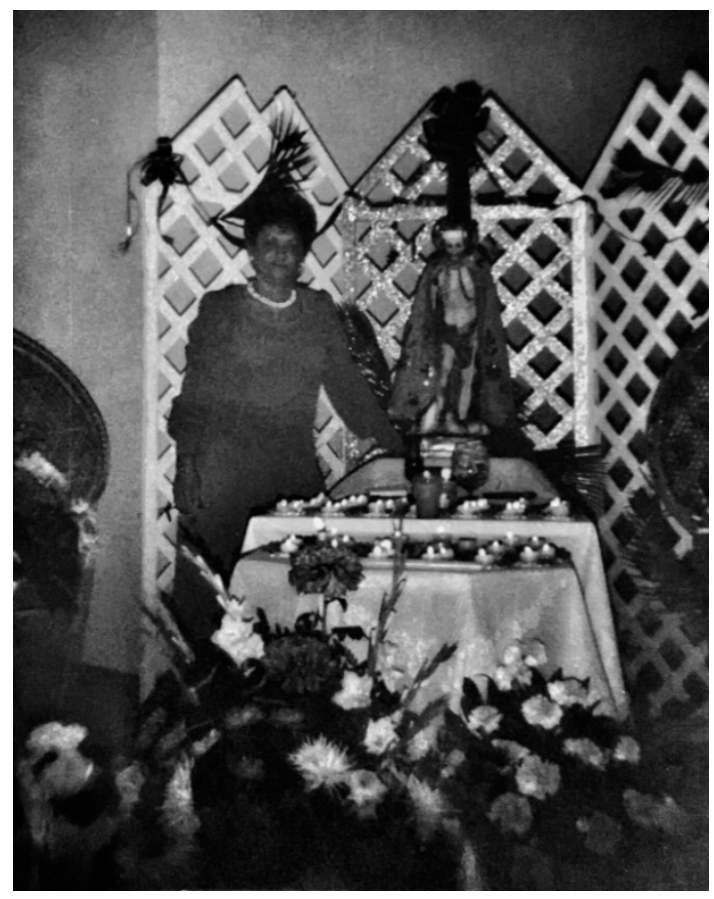

Figure 3. While looking through old family photographs, I often spot San Lázaro's image somewhere in the frame. Whether as a charm hanging on my abuela's necklace, standing outside her front door, or towering over a group of Cuban devotees dancing in a banquet hall on 17 December, San Lázaro was always there. I recall attending the saint's elaborate yearly feast day celebrations as a child. These celebrations were sponsored by a Cuban fraternal organization in Miami, Florida, called Municipality of Cabaiguán in Exile. At these celebrations, there was always a large statue of San Lázaro (pictured here with my abuela) adorned with a purple and gold cape, surrounded by candles and purple and yellow flowers, and sometimes other offerings like money, tobaccos, dry wine, and even certain food items. Photo courtesy of the author c. 1986.

The story of her emigration to the United States is among the most repeated by my abuela and the one she uses to locate the origins of her faith in San Lázaro. My abuela always worked in physically laborious conditions. She grew up working on her family's tobacco farm in Cuba. When she moved to the United States, the only job she could find that did not require her to know English was at a factory that manufactured doors and windows. She worked long hours on her feet, and as a result, her knees and feet weakened. The day came when my abuela could no longer tolerate the pain in her feet and had to leave her job at the factory. Soon thereafter, she needed orthopedic surgery. The recovery process was long, and I vividly recall my abuela lying on the couch in our living room with bags of ice over her recently operated feet. I would stay by her side for hours, making sure to bring her fresh bags of ice whenever she needed them. I remember that she would pray to San Lázaro every night to ease her pain and expedite her recovery. She never took off the necklace that held the charm bearing his image. See Figure 4. As a child, her recovery seemed miraculous; one day, she was lying on the couch with bags of ice on her feet, and the next she was up and about. Although I am sure that significant time elapsed in between, I cannot recall any other memories of her recovery process. In conversations with my aging abuela about this time in her life, she seems only to remember how painful her recovery was and how she would have never overcome it without San Lázaro. 


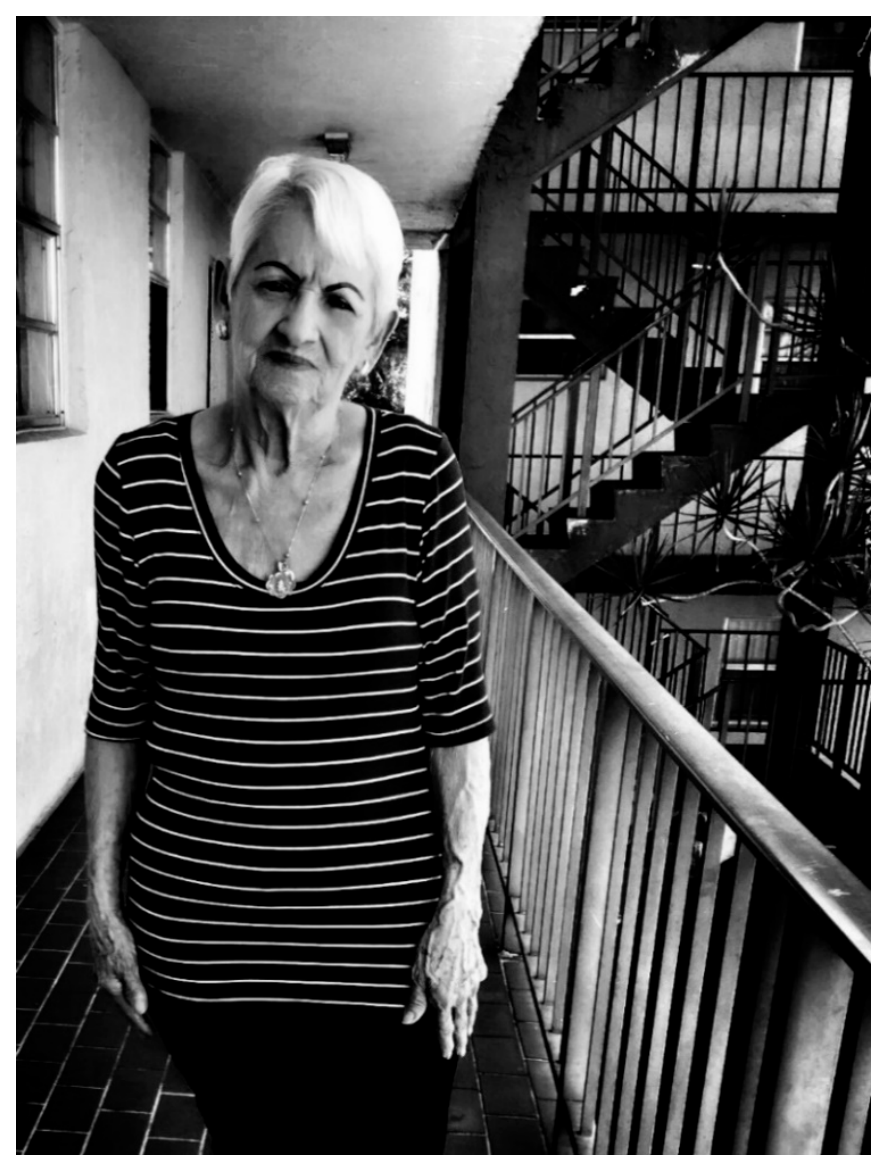

Figure 4. At 85, my abuela continues to wear her San Lázaro medallion on her necklace. A few years ago, while she was ill, she told me she wanted me to pick whatever I wanted to keep of hers when she passed away. I told her the only things I wanted were her saint statues and her necklace, where she wears an assortment of saint charms and other religious items. Not wanting to wait, my grandmother took off her necklace and told me to take it then and there. I told her I did not want her to be without it, but she insisted. A few weeks later, my abuela was still feeling unwell. She told me she had a dream about her San Lázaro medallion and that the reason she was still feeling sick was because she was not wearing it. She asked me if it would be okay to give her back just that one charm from her necklace and that I could have it back when she passed away. I, of course, obliged and promptly went to her apartment to return San Lázaro's medallion. Photo courtesy of the author 2019.

We were tobacco farmers

In Cuba, before I left

In search of freedom

I tried to work

At a cigar company

But the smoke sickened me

I was strong

But did not know English

So, I found a factory job

Making doors and windows

Does not require

Talking, or, reading, or writing

Just physical labor

On my feet

Day after day

Surgery was the only option 
I could not stand

With so much pain

But with bags of ice

And you by my side

San Lázaro helped me heal

\section{From Familial Faith to Research}

My familial experiences with San Lázaro eventually lead me to learn about others' devotion to the saint. During my time as a graduate student at the University of Denver, I made San Lázaro the focus of my studies in lived religion by traveling home to South Florida to conduct ethnographic research at Rincón de San Lázaro church. My experiences and observations at the church culminated in my degree completion project (focused on the symbolic language of San Lázaro). Bringing together the importance of San Lázaro's altar for my abuela and the devotees at Rincón, I decided that it was crucial to my project to create an altar of my own during my defense in order to dedicate an appropriate sacred space for my academic undertaking where San Lázaro and the material elements of his devotion were at the center. Intuitively picking up on the unspoken importance that my abuela placed on San Lázaro's cape, I asked her if she would send me one of her handmade capes to use in the construction of an altar for a school project. Always one to indulge my requests, my abuela mailed me a cape to Colorado from Miami, where she still resides.

I knew that the best way to honor my understanding of my abuela's faith was to make my own cape for San Lázaro, but my lack of sewing skills coupled with the time constraints while finalizing my degree did not allow me to do so. As I prepared to defend my completion project on San Lázaro, I made a list of the various items I would need for the saint's altar. The time I hoped to dedicate to gathering the altar items (a cigar, 17 pennies, mixed beans without lentils, burlap cloth, a prayer candle, dry white wine, toasted corn, green coconut water, and purple flowers) turned out to be much longer, as it was exceedingly difficult to find some of the items in the area of Colorado where I was living. In the end, I wound up emulating my abuela's patient dedication to her cape-making devotional labor by sorting through a bag of mixed beans to carefully and painstakingly remove any lentils (lentils remind Babalú Ayé of his pockmarks and therefore must be removed from his mixed bean offerings), making my own prayer candle, and spending hours finding everything else I needed for San Lázaro's altar. While I did not inherit my abuela's sewing skills, her faith in San Lázaro and her stories about the role the saint has played in her life instilled in me a similar regard and patience in my faith and scholarly practices. Her narratives of healing became genealogical healing narratives for my incredulity and impatience.

Much of what I experienced at Rincón remained unused in the academic sense and sat in storage between my memory, field notebook, and computer. However, the COVID19 pandemic urged me to revisit my San Lázaro files as I continuously contemplated what it meant to heal during the early months of social isolation. Reflecting on San Lázaro, the patron saint of the sick and the poor, felt poignant and ironically apt during a time when the novel coronavirus assaults the very breath we use to pray. As I read my notes, looked through photographs, and tried to find meaning in the current pandemic, part of what became clear was that what I experienced at Rincón was my abuela's faith exponentially multiplied. I also discovered that my genealogical experience with faith was a prevalent theme brought up by my interlocutors. I encountered lo cotidiano in the everyday expressions of faith and devotion to San Lázaro. Most of my photographs might be described as mundane; they do not show what some might deem spectacular performances of faith, such as prostrations or manifestations. However, a more nuanced look reveals defining aspects of lo cotidiano present throughout the church and its visitors. See Figures 5-12. 


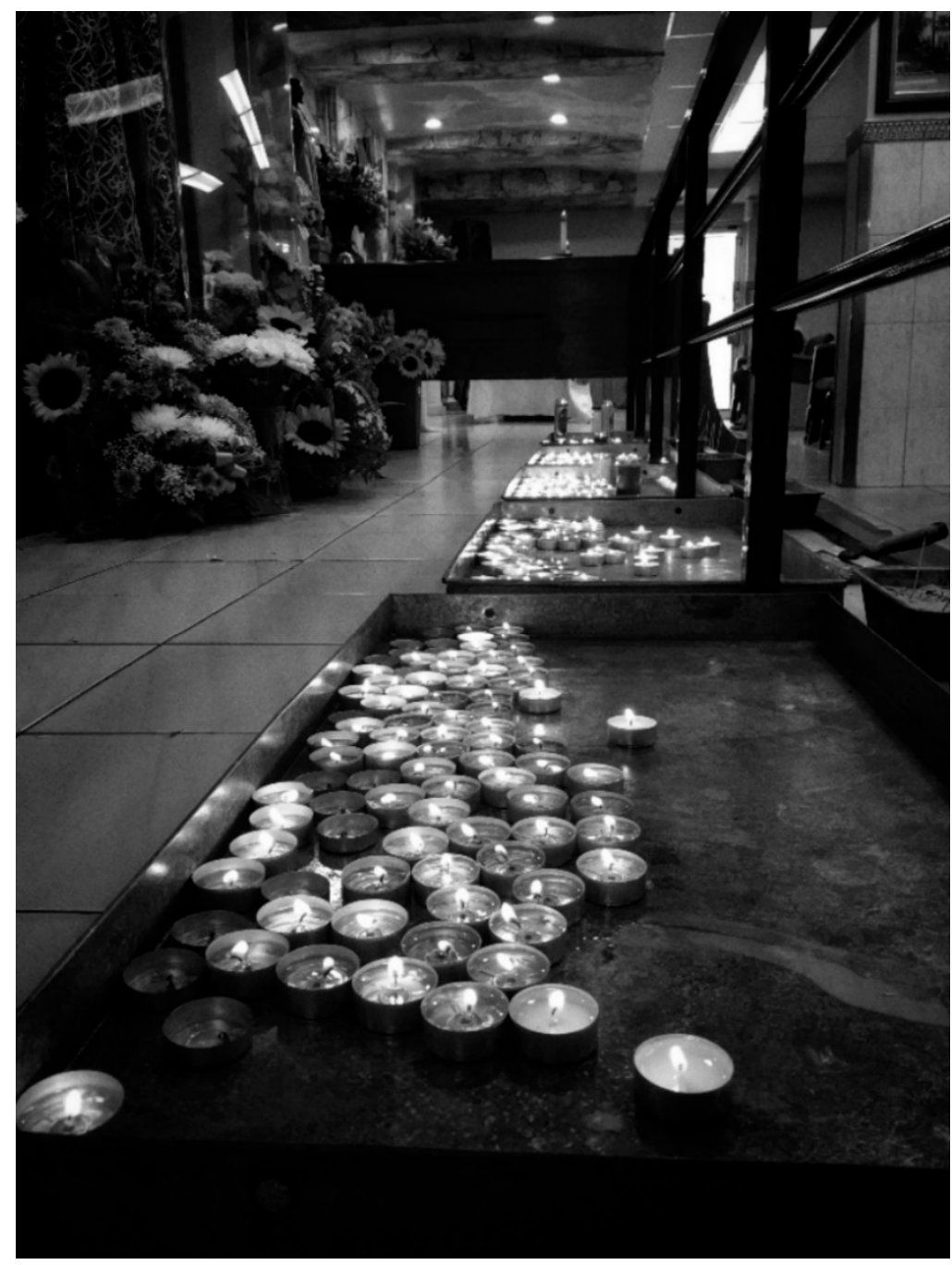

Figure 5. As part of the services provided to the community of devotees, Rincón de San Lázaro church gives out small tea lights to anyone who wants to light a candle for San Lázaro. On any seventeenth of the month (except on San Lázaro's feast day on 17 December), Rincón's bishop estimates that approximately one thousand parishioners visit the church, meaning that more than one thousand candles will be given out freely and lit for San Lázaro as a part of devotees' prayer rituals. Because the number of candles is so great, the church requires that visitors place the tea lights on galvanized steel trays to catch dripping wax and help prevent fires. Photograph by author 2016. 


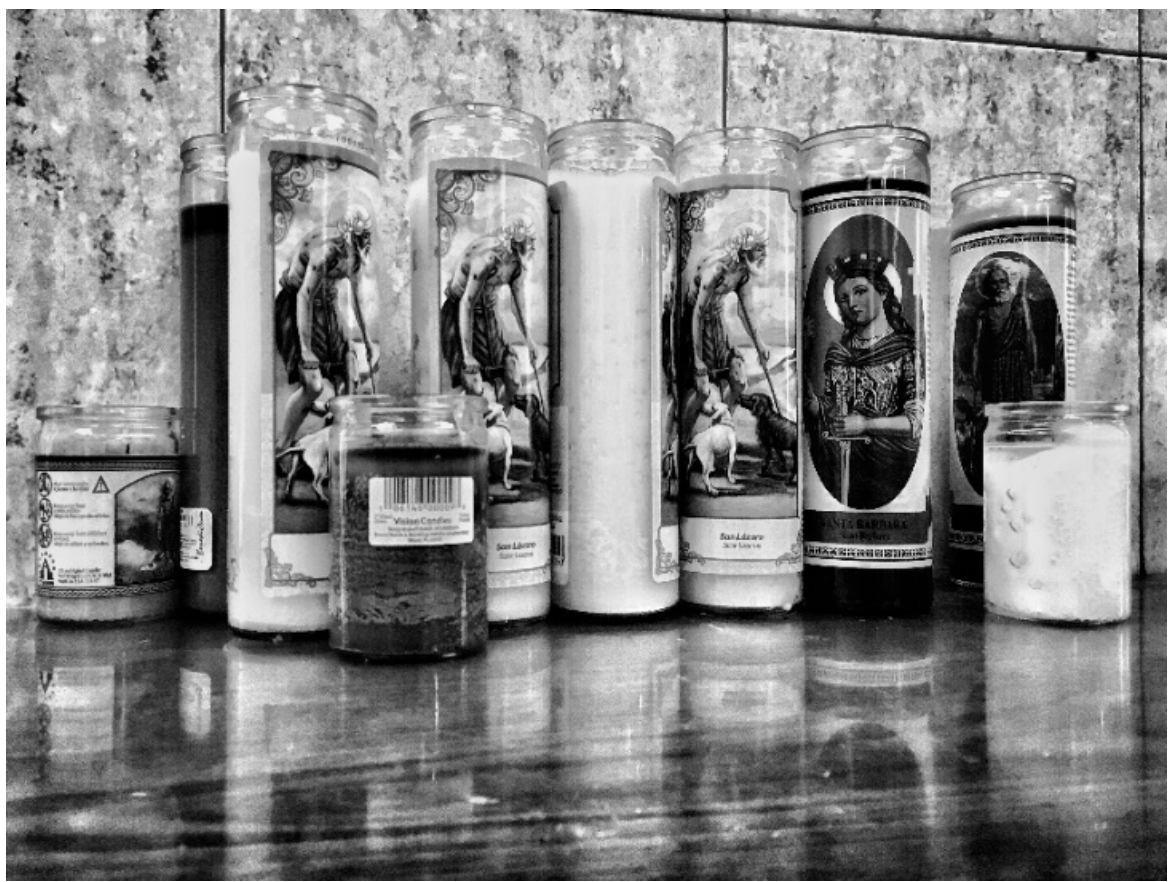

Figure 6. Despite the free candles given out by the church, devotees often bring their own glass votive prayer candles to Rincón. After a few visits from the concerned local fire marshal, the church decided to only permit their metal-encased tea lights on San Lázaro's altar. This policy, enacted no doubt to appease the fire department and help reduce the chances of a potentially catastrophic fire in the sanctuary, has not deterred visitors from bringing the forbidden prayer candles. Raphael, the man in charge of overseeing the altar while the church is open, is always busy arranging flowers brought to San Lázaro by parishioners and monitoring contraband candle lighting. Photograph by author 2016.

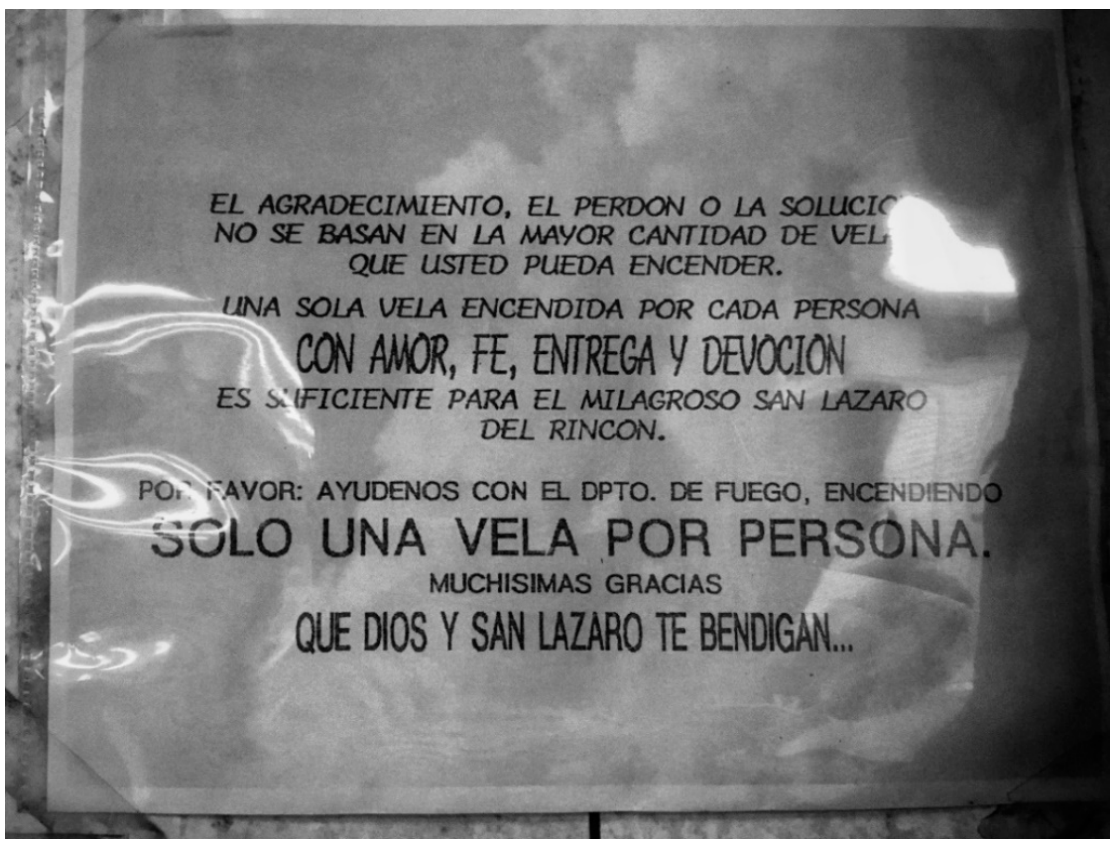

Figure 7. A laminated paper sign near the church's front office reads, "Gratitude, forgiveness or the solution are not based on the quantity of candles you can light. A single candle lit by each person with love, faith, surrender and devotion is sufficient for the miraculous San Lázaro of Rincón. Please, help us with the fire department by lighting only one candle per person. Thank you very much. May God and San Lázaro bless you ... " Photograph by author 2016. 
Candles light the way

For our prayers

To reach their destination

Limited to one per person

Pools of melting wax

Drip onto metal trays

Weary over our candle-lit ways

Our glass votives are forbidden

But we bring them anyway

Because our saints are on them

Their flames illuminate

Our printed supplications

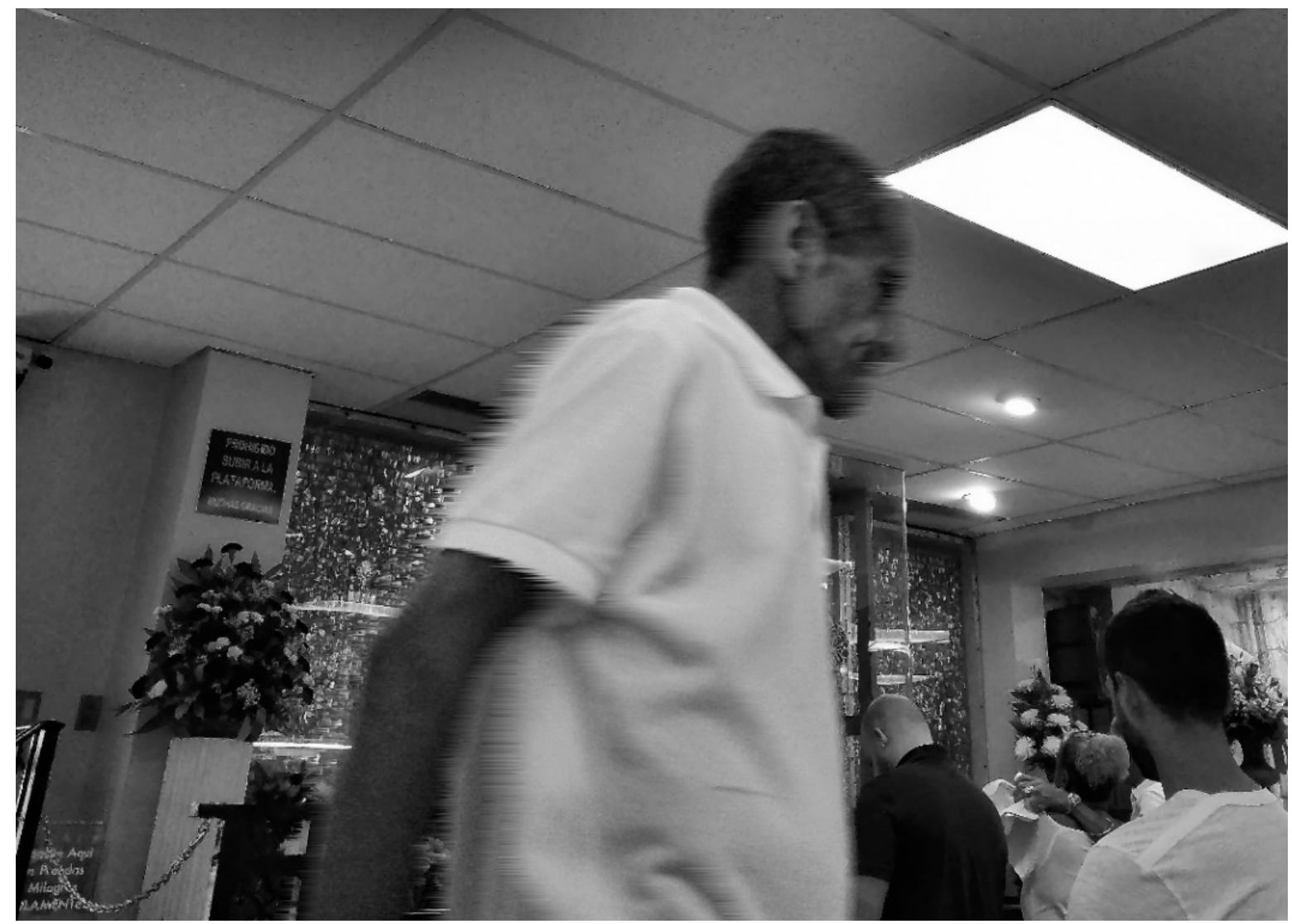

Figure 8. Always on the go, Raphael, the altar overseer, is in constant motion while the church is open. Between monitoring candles, filling flower vases, and making sure that no one walks up onto the altar, his duties are incessant and seemingly little appreciated by visitors. After becoming irritated at a woman talking on her cell phone, he tells her she has to leave the altar area if she is going to continue to talk on the phone. Raphael walks away, muttering, "people have no respect." A little while later, he returns, and the woman approaches him to apologize, explaining that she was on a call with family from Cuba. He apologizes and tells her that calls from Cuba are excused. They hug, and mimicking a priestly tone, he tells her, "you are forgiven." The woman leaves with a smile. Photograph by author 2016. 


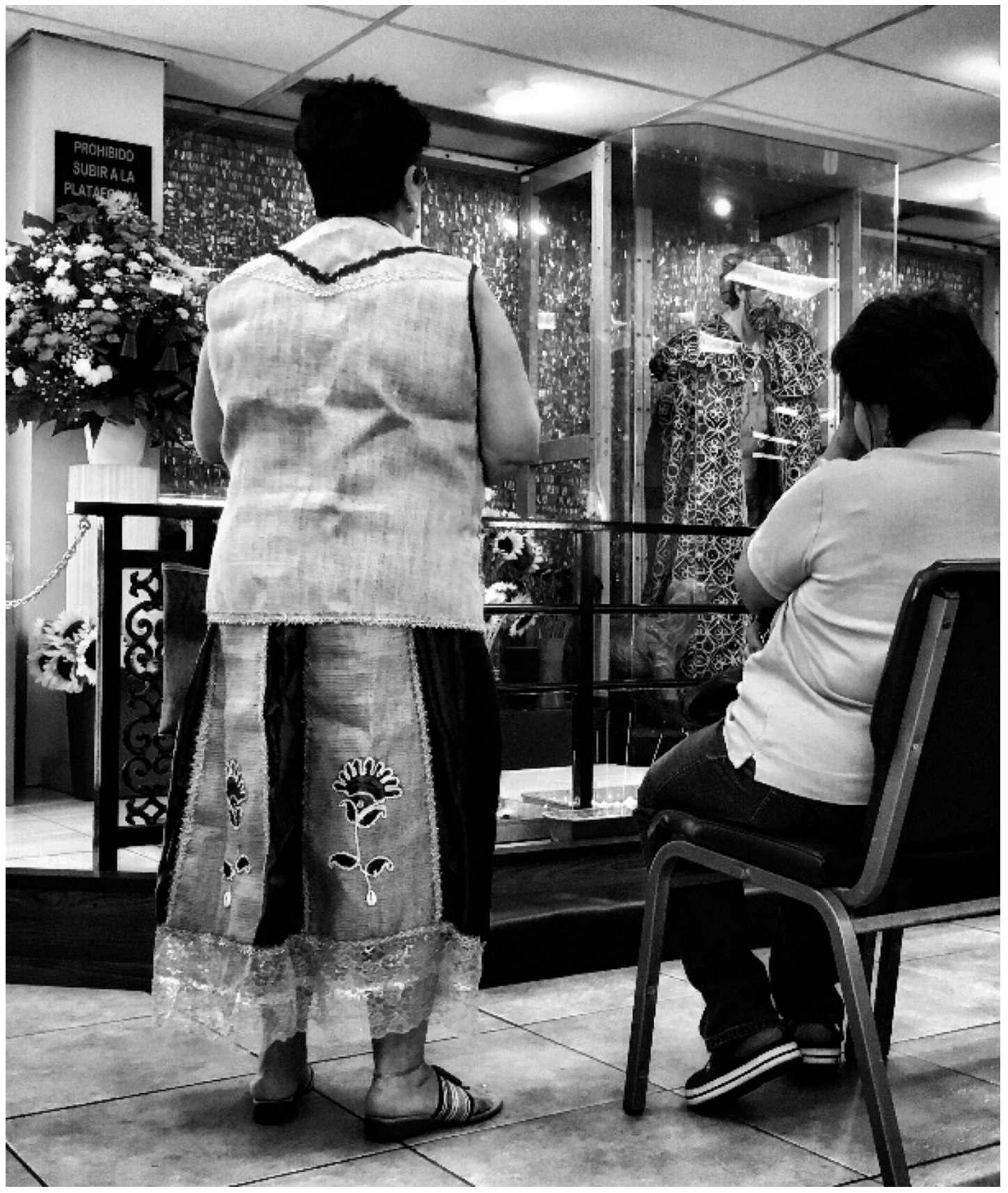

Figure 9. The use of burlap among San Lázaro devotees is perhaps one of the most fascinating aspects of the saint's symbolic language that contributes to the genealogical healing narratives passed on by his believers. His devotees wear burlap clothing as a sign of devotion or as fulfillment for a promise made to him. Wearing burlap links San Lázaro's devotees to his poverty and suffering and mirrors the painful experience of his diseased body. Other promises made to San Lázaro include bringing him flowers, candles, cigars, money, or milagritos (charms in the shape of body parts that devotees will give to the saint to thank him for healing them or a loved one). Photograph by author 2016. 


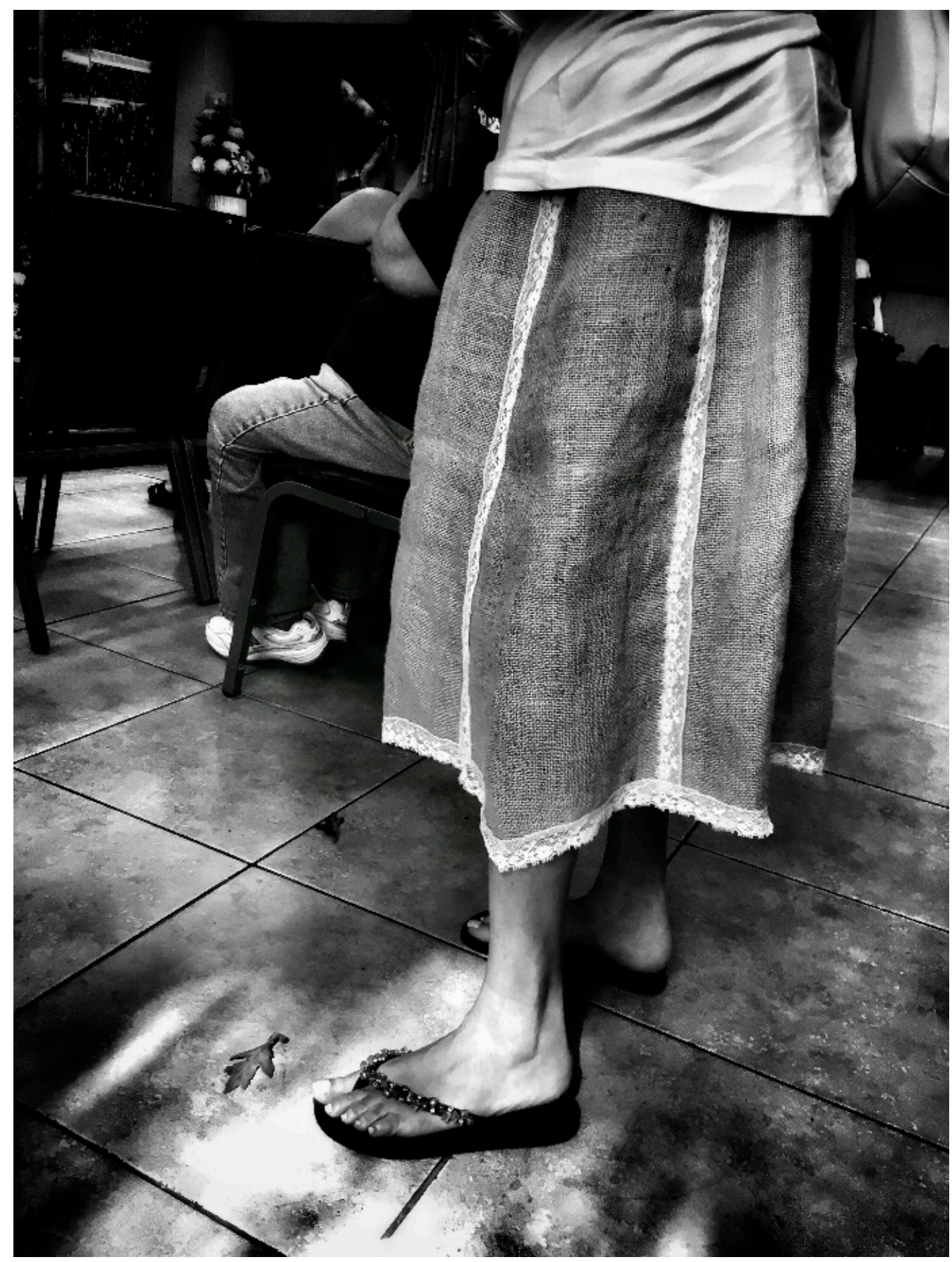

Figure 10. During my time at Rincón de San Lázaro, I witnessed several individuals coming to the church dressed in burlap clothing. Most of the clothing appeared custom-made and ranged from simple skirts to more elaborate outfits, including embroidered burlap vests, pants, and jackets. The symbolic importance of interweaving purple cloth and burlap was evident among devotees wearing these custom-made outfits. I also witnessed a woman wearing a burlap skirt who crawled on her knees from the front door of the church to San Lázaro's altar. For San Lazaro's devotees, wearing burlap is a way in which they experience the saint through their skin. This public act of devotion is more than a performance of faith; it is the enfleshing of belief in San Lázaro's healing powers. Photograph by author 2016. 


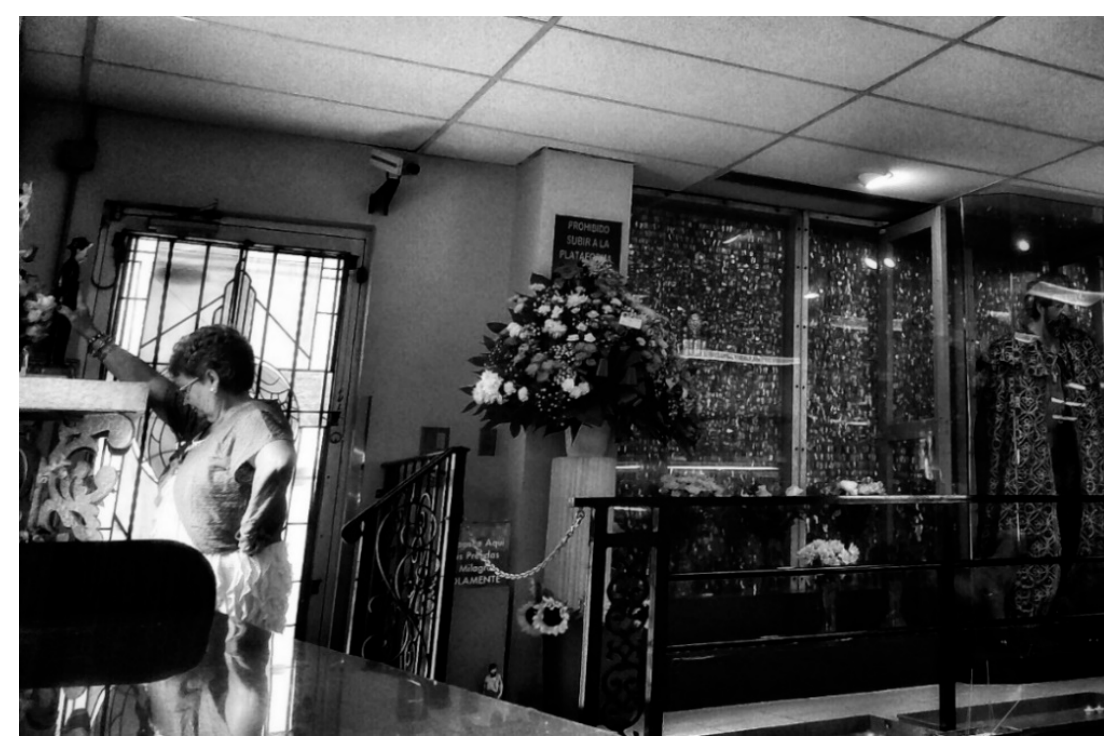

Figure 11. San Lázaro shares his church with other powerful saints popular among the Latinx community of South Florida. Due to the number of visitors who wish to come into physical contact with San Lázaro's effigy, his towering statue is kept behind a doubly protective enclosure, as is the large statue of Santa Barbara, located near the front of the church. Small statues of many of the saints popularly worshipped by Cubans and Cuban-Americans are similarly protected in the church. After lighting a candle and praying to San Lázaro, a woman moved to an area just to the left of the saint's effigy, where a small altar to the venerable Dr. José Gregorio Hernández is located. Placing her right hand on the small statue, the woman bowed her head and prayed. She remained in this position for a few minutes before marking herself with the sign of the cross and walking away. Dr. José Gregorio Hernández's statue is among the few in the church available to visitors for direct contact since it is not behind a protective barrier. Photograph by author 2016 .

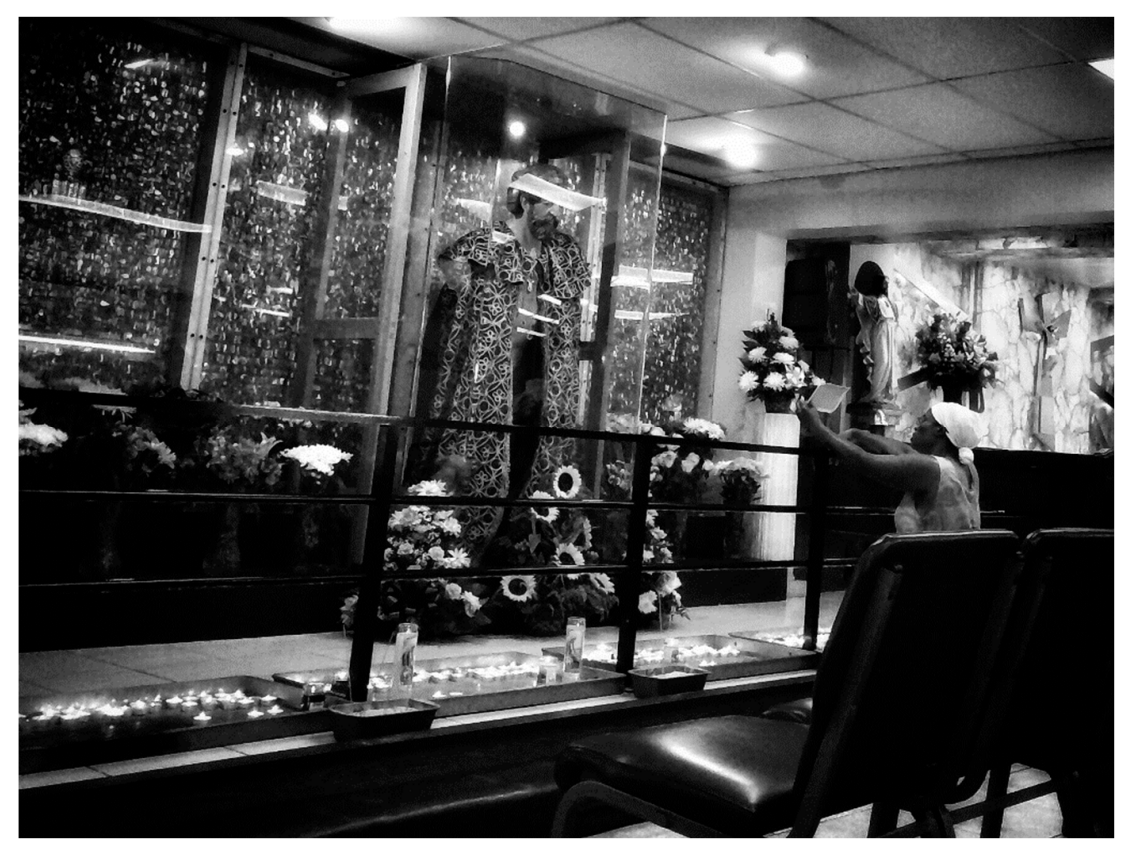

Figure 12. Kneeling in front of San Lázaro, a woman holds up an envelope of some sort and petitions the saint for his help. Due to the saint's association with the poor man Lazarus in the Gospel of Luke, it is not uncommon for devotees to seek out San Lázaro's help with financial and legal matters as part of his holistic healing capabilities. A few of the men I spoke with at the Rincón also mentioned asking San Lázaro for help when they desired to leave Cuba to come to the United States. Photograph by author 2016. 
We touch casts of plaster

And kneel before you

This is how we heal

With offerings of tobacco

Lit candles and purple flowers

This is how we heal

Collecting bags of pennies

To leave tithings at your feet

This is how we heal

Adorning your altar

With charms of gold and silver

This is how we heal

Wearing the color purple

And vestments of sack and burlap cloth

This is how we heal

Donning these garbs

To feel your skin upon on our skin

This is how we heal

Fulfilling promises made

In return for promises kept

This is how we heal

With devout faith

And remembering your stories

This is how we heal

Rewriting your history on our flesh

Unifying your suffering and ours

This is how we heal

Passing on your stories

And the testimonies of your grace

This is how we heal

In communion with you

And our neighbors who call you

San Lázaro and Babalú Ayé

This is how we heal

\section{Genealogical Narratives of Healing}

Devotion to San Lázaro serves as a prime example of the construction and transmission of genealogical narratives of healing among Cubans and other Latinx communities. For many devotees, faith in San Lázaro is part of a genealogical narrative of healing inherited from close family members, often a mother, grandmother, or great grandmother. These genealogical narratives of healing contain familial stories of faith, witnessing, and above all, testimonies that recall San Lázaro's power to alleviate or heal suffering. Within Cuban and Cuban-American culture, it is not uncommon for parents to name their children after the saint as a sign of devotion or gratitude for received healings; this is also a common cultural occurrence for children of the devout born on December 17th, the saint's feast day. Naming a child Lázaro or Lázara (the feminized iteration of the saint's name) is often a signifier of a familial relationship with the saint. The act of naming a child after San Lázaro is a genealogical gesture that contributes to the production of genealogical narratives of healing.

In the most recent scholarship on San Lázaro veneration, Todd Ramón Ochoa writes an ethnographic history of ancestral devotion to the popular saint that spans six generations of a Cuban family in Villa Clara Province, Cuba (Ochoa 2020, p. xiii). His work focuses 
on what he terms a "compounded" understanding of San Lázaro, where the identities of Lazarus from the Gospel of Luke and Lazarus from the Gospel of John become a "doubled santo (saint)" to which is added to the identity of the orisha of disease, Babalú Ayé (Ochoa 2020, pp. 8-9). "Only San Lázaro-Babalú Ayé is master of illness and the suffering that accompanies it, including pain and worry. He is also master of healing and recovery," Ochoa maintains (Ochoa 2020, p. 36). It is because of this dichotomous power over human affliction that the Cuban San Lázaro commands such deep respect and devotion from his believers. Familial stories about experiences with San Lázaro provide testimony of the saint's efficacy, rendering his intervention or intercession with the experience of illness or disease a memorable event for families.

In speaking to devotees of this popular saint and reflecting on my relationship with him, it becomes clear that San Lázaro's miraculous healing powers are partly due to the transmission of his stories and the countless testimonials that his devout are willing to share. While some devotees share their faith orally, many others do so through a sort of public silence by wearing his colors, donning clothes made of burlap or sackcloth, or carrying his likeness on their bodies in the form of necklace charms or prayer cards. Existing in a similar liminal space that so many Cubans, Cuban-Americans, and Latinx peoples exist in, San Lázaro conveys the emotional experience of diaspora, as well as a sense of hope for a life outside the bounds of disease and poverty. As a result, San Lázaro serves as an important healing figure not just for Cubans and Cuban-Americans but for people from all over the world. San Lázaro represents the history of Latin America, the Caribbean, and of life on the hyphen. The saint reifies his position-on the side of the poor and marginalized-by retaining the symbols of disease and oppression on his body, even after the elevation of his status to a popular saint. He exemplifies lo cotidiano and remains common and accessible through his body and his stories, which represent the struggles of his devotees.

Faith and healing directly correlate for devotees of San Lázaro. His abilities to heal are undeniable for the faithful seeking recuperation from physical ailments and other oppressive forms of suffering. Devotees, while mainly identifying as Catholic, often pray directly to San Lázaro and make offerings to him in exchange for healings. San Lázaro's primary means of communication with devotees is through healing. The concept of healing is, therefore, foundational to the relationship between the saint and those who venerate him. Through the stories of San Lázaro's devotees, we can understand how and why devotion to this popular saint sustains such a prominent place among a variety of religious traditions, which include Catholics and practitioners of African heritage religions such as Santería/Lucumí. Healing - received through faith in San Lázaro-is the reason why devotees from across religious and ethnic lines trust in the saint. A communal understanding of healing, therefore, renders San Lázaro efficacious for diverse populations. The stories that devotees tell about their experiences of healing through faith in San Lázaro constitute a type of narrative medicine, which I refer to as genealogical healing narratives, that the devout tell to others as proof of the saint's effectiveness. Moreover, the sharing of healing experiences through family stories and personal testimonies creates a nonproselytizing way of passing down faith in San Lázaro from generation to generation among Latinx communities. Testimonies of the saint's efficaciousness are at the heart of genealogical narratives of healing.

Most of the conversations and formal interviews I had during my time at Rincón revealed something, directly or indirectly, that pointed to the genealogical nature of each individual's faith in San Lázaro. For most, devotion to the saint is an inherited part of their religiosity, often connected to the women in their families, like mothers, grandmothers (as in my case), and great grandmothers. For others, their devotion to the saint was caused by a profound need for healing, whether for themselves or a beloved family member. Through their faith practices, these individuals are the progenitors of faith in San Lázaro, who will likely pass on their beliefs to family members by sharing the stories of their healing experiences. The following participant-voiced poems are derived from stories 
shared with me by four individuals at Rincón. These poems each reveal genealogical narratives of healing from inheritors and progenitors of devotion to San Lázaro.

\section{Cleotilde}

Faith is a part of my family's tradition

Venerated him since before I was born

I have believed in San Lázaro

Since I first opened my eyes

I pray and light candles

I go to Rincón

I speak to him

And collect holy water

Faith can move mountains

I pray for my health

Six months since my surgery

I am cancer-free

Can I bring a prayer card with me?

I asked the doctor

When I had surgery

San Lázaro was with me

He healed my cancer

And my knees

(Laughing)

I even pray to him for my hair

When I wake up

Before I go to sleep

And whenever I get in a car

I thank him for keeping me safe

Cleotilde, a Cuban woman in her seventies, was enthusiastic about sharing her story with me. Showing me a similar type of openness that I experience from my abuela and many other Cuban women from a similar generational group, she related the genesis of her faith in San Lázaro with her birth. Signaling to the genealogical reach of devotion to the saint within her family, Cleotilde also mentioned that she has a nephew in Cuba who is a devotee of San Lázaro. She said the saint has helped him with his health and that on San Lázaro's feast day, he wears clothes made of burlap. She continued by saying that her nephew does not work on San Lázaro's feast day and that he spends those days in complete silence. As inheritors of faith in San Lázaro, Cleotilde and her nephew demonstrate the continuation of genealogical narratives of healing. Through her actions and her description of her nephew's faith practices, Cleotilde reveals deeply embedded aspects of Babalú Ayé in San Lázaro's healing potentials. Cleotilde's correlation between the healings she received and San Lázaro falls outside the realm of Catholic orthodoxy where the saints have no power to effectuate change on their own. For devotees like Cleotilde, San Lázaro is so powerful because his own genealogy mirrors the complex historical identity of the Cuban people.

\section{Lázaro Ruben}

My great grandmother

My grandmother

My mother

They were all devout to him

I inherited my faith

From these three women

My mother is so devoted 
She named me after him

I prefer to use my middle name

In Cuba, all the saints have two names

Part of the syncretic cult of saints

They all have African origins

When my father was ill

I would pray to San Lázaro

Before he passed away

He was happier because he had faith

I don't ask him for things

I just give thanks

You have to put effort

Unless something is without remedy

Sitting in the pews with his elderly mother one Sunday, Ruben, a Cuban man in his late fifties, said that his faith in San Lázaro stems from a matrilineal heritage handed down to him by three generations of women. In Ruben's story, we see how genealogical narratives of healing became genealogical healing narratives for his father before his death. In correlation with popular naming practices among Catholics with a strong devotion to saints, Ruben's story also demonstrates the depth of his mother's relationship with San Lázaro. Unlike others to which I spoke to during my time at the church, Ruben directly pointed to the complex identity of the Cuban San Lázaro, stopping short of referring to him as Babalú Ayé. Building on the use of his preferred name, Ruben acknowledged the African origins of San Lázaro's vast healing powers.

\author{
Alexander \\ My faith comes from my grandmother \\ She was a devotee \\ When I was a child \\ She would take me to Rincón \\ It started as a way \\ To show my respect \\ To find peace \\ Because I loved her so much \\ After I left Cuba \\ She passed away \\ I've never asked for healing \\ I only give thanks \\ Thanks to him, I'm a better person \\ San Lázaro is always watching \\ If I make a mistake \\ I ask for forgiveness \\ San Lázaro is very good \\ As long as you keep your promises \\ He is very just \\ And I am a very obedient person
}

Alexander, a Cuban man in his early thirties, stood outside the front doors of the church with me and shared that his faith in San Lázaro is also genealogical in nature, in his case stemming from his grandmother. As a devotee of San Lázaro's, his grandmother would travel to the Santuario Nacional de San Lázaro and take Alexander with her when he still lived in Cuba. For Alexander, San Lázaro provided healing, not from a physical ailment, but from the emotional and psychological pain he experienced after the death of his beloved grandmother. Alexander also lamented that some people only come to San 
Lázaro when they need something. Alexander said he has never been seriously ill, but when he has suspected that he is going to get sick, he comes to the church and prays. He says that because he does this, he has never gotten ill.

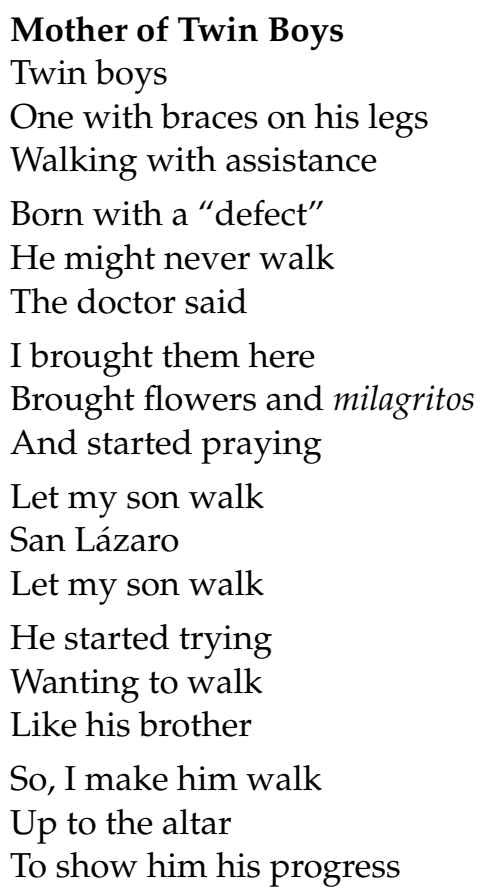

A young couple appearing to be in their mid-twenties came to the church with their 2-year-old twin boys. Not having time for a formal interview (or to give me her name), the mother of the boys briefly shared her San Lázaro story. She said that one of her sons was born with a condition that she termed a "defect," which prohibited him from developing strength in his legs. The doctor's prognosis revealed that it was very likely that he might never walk like his twin brother. Unwilling to accept this outcome for her son, she said she started bringing her sons to Rincón and praying to San Lázaro. She believes that her son's recent desire and successful attempts to walk are a sign that San Lázaro is responding to her supplications. Before parting ways, she mentioned that her son (the one with braces on his legs) always leaves the church happy, laughing, or giggling as he walks out. The mother, through her refusal of the medical prognosis for her son, is progenerating devotion to San Lázaro for her young family. While it remained unclear if she sought out San Lázaro because of existing familial tie to the saint, based on the stories shared with me by other devotees, it seems likely that her son's ability to walk despite the doctor's grim prognosis will become a genealogical narrative of healing for her family.

\section{Conclusions}

Contrary to official Catholic doctrine on saint veneration, devotees who mainly identify as Catholic often pray directly to San Lázaro, establishing a relationship of reciprocity through their familial practices of offerings and promises in exchange for healings. Everyone I observed arriving at Rincón de San Lázaro church crossed themselves upon entering and leaving the building, pointing to their religious identities as corporeal Catholics. Even though most congregants were at the church to pray to a saint that is not recognized by the Vatican, this gesture demonstrated their commitment to their individualized understanding of Catholicism. For his devotees, San Lázaro is an effective figure whose power to heal cannot be confined by religious doctrine. Despite efforts by the Catholic Church, Cubans and Cuban-Americans remain committed to San Lázaro and hold steadfast to their beliefs in his ability to heal the faithful. As the stories of several devotees have demonstrated, for many Cubans living in the U.S., devotion to San Lázaro is rooted at the genealogical level, embedded within familial, religious traditions, and cultural practices 
far too deeply to be extracted or corrected by institutionalized religion. Paired with the exilic experience profoundly felt by so many Cubans that migrated to the U.S., San Lázaro's mythologies emerging from biblical and African heritage sources provide a path toward healing desperately yearned for by Cubans longing for their homeland.

The stories that the devout share about San Lázaro are genealogical narratives of healing that enable his devotees to connect with the saint and pass on the stories of his healing abilities. Stories about San Lázaro and my observations at Rincón de San Lázaro church confirm that his grace accessible for all of his devotees regardless of ethnic or religious background. Therefore, healing for devotees of San Lázaro is constructed on the premise of understanding and sharing these narratives. As demonstrated, the concepts of faith and healing are intertwined for devotees of San Lázaro. His ability to heal the faithful is evident throughout the stories, poems, and photographs presented here. Lo cotidiano and its relationship to healing and is also evident through these mediums. Stories about San Lázaro exemplify the egalitarian and varied nature of disease. Because the various aspects of this saint's identity all in some way deal with issues of health and disease, life and death, and poverty and wealth, it is understandable that his devotees consider him the patron saint of the poor and ill. Genealogical narratives of healing perpetuate belief in San Lázaro and, in turn, create opportunities for the devout to heal.

Funding: The ethnographic research informing this article was partially funded by a 2016 Arts, Humanities, and Social Sciences summer research grant from the University of Denver.

Institutional Review Board Statement: Ethical review and approval were waived for this study by both the University of Denver IRB and Emory University IRB. The University of Denver IRB determined that the research undertaken for this study did not fulfill the regulatory definition of research even though it involves human subjects per the federal regulation definition. Emory University's IRB also determined that the research undertaken for this study did not require IRB review because it does not meet the definition of "research" with human subjects as set forth in Emory policies and procedures and federal rules, if applicable.

Informed Consent Statement: Informed consent was obtained verbally from all subjects involved in the study.

Data Availability Statement: Not applicable.

Acknowledgments: My heartfelt gratitude goes out to the devotees of San Lázaro, who were generous enough to share their stories with me; this work could not have been done without your trust and openness. And to my abuela, who taught me to pray and was my first religious instructor, gracias por compartir tu fe en San Lázaro conmigo. Siempre lo llevaré en mi corazón.

Conflicts of Interest: The author declares no conflict of interest.

\section{References}

Canizares, Raul, and Eric Lerner. 2000. Babalu-Aye: Santeria and the Lord of Pestilence. Plainview: Original Publications.

Charon, Rita. 2006. Narrative Medicine: Honoring the Stories of Illness. New York: Oxford University Press.

Colaboradores de EcuRed. n.d. "Santuario Nacional de San Lázaro," EcuRed. Available online: https:/ /www.ecured.cu/index.php? title=Santuario_Nacional_de_San_L\%C3\%A1zaro\&oldid=3527290 (accessed on 11 November 2020).

Cros Sandoval, Mercedes. 2006. Worldview, the Orichas, and Santeria: Africa to Cuba and Beyond. Gainesville: University of Florida Press. Ellis, Carolyn. 2004. The Ethnographic I: A Methodological Novel about Autoethnography. Walnut Creek: AltaMira Press.

Ellis, Carolyn, Tony E. Bochner, and Arthur P. Adams. 2011. Autoethnography: An Overview. Forum Qualitative Sozialforschung/Forum: Qualitative Social Research 12. [CrossRef]

Gonzalez, Michelle A. 2006. Afro-Cuban Theology: Religion, Race, Culture, and Identity. Gainesville: University of Florida Press.

Holman Jones, Stacy. 2005. Autoethnography: Making the Personal Political. In Handbook of Qualitative Research. Edited by Norman K. Denzin and Yvonna S. Lincoln. Thousand Oaks: Sage, pp. 763-91.

Isasi-Díaz, Ana María. 2002. Lo Cotidiano: A Key Element of Mujerista Theology. Journal of Hispanic/Latino Theology $10:$ 5-17.

Leavy, Patricia. 2015. Method Meets Art: Arts-Based Research Practice. New York: The Guilford Press.

Nanko-Fernández, Carmen M. 2015. Lo Cotidiano as Locus Theologicus. In The Wiley Blackwell Companion to Latino/a Theology. Edited by Orlando O. Espín. West Sussex: Wiley Blackwell, pp. 15-34.

Ochoa, Todd Ramón. 2020. A Party for Lazarus: Six Generations of Ancestral Devotion in a Cuban Town. Oakland: University of California Press. 
Peña, Elaine. 2011. Performing Piety: Making Space Sacred with the Virgin of Guadalupe. Berkeley: University of California Press.

Rincón de San Lázaro. About Us. Available online: https:/ / rincondesanlazaro.org/en/about-us/ (accessed on 11 November 2020). 